\title{
Changing Our Mind: Beta Cell Workload Hypothesis
}

\section{Yoshifumi Saisho*}

Department of Internal Medicine, Keio University School of Medicine, Tokyo, Japan

Despite recent advances in treatment options for type 2 diabetes (T2DM), the prevalence of T2DM continues to increase throughout the world [1]. A healthy lifestyle is a key factor in both treatment and prevention of T2DM. A healthy lifestyle cannot be established without self-management ability. Better understanding of the pathogenesis of T2DM will improve self-management ability.

T2DM is characterized by insulin resistance and beta cell dysfunction, which result in insufficient insulin action, leading to chronic hyperglycemia. However, since obesity is a major risk factor for T2DM, and hyperinsulinemia is also observed in individuals with T2DM, insulin resistance is often emphasized as a characteristic of T2DM. In contrast, since insulin resistance is considered to be accompanied by hyperinsulinemia, beta cell dysfunction is often ignored in these subjects.

However, recent studies showed that beta cell dysfunction, but not insulin resistance, is critical for the development of T2DM [2]. Even in the obese subjects with T2DM, beta cell function and mass are reduced $[3,4]$. These data suggest that beta cell dysfunction is the common pathogenetic feature of both type 1 and type 2 diabetes (Figure 1).

Our and others' data suggest that the ability of expansion of beta cell mass in adult humans is markedly limited (0 to 50\%) [5-7]. Considering the fact that insulin secretion is two to three fold increased in obese individuals [8], the workload of each beta cell is presumed to

\begin{tabular}{|c|c|c|}
\hline \multirow[t]{3}{*}{ Past } & & \\
\hline & Type 1 diabetes & Type 2 diabetes \\
\hline & $\begin{array}{l}\text { Beta cell destruction } \\
\text { Beta cell mass } \downarrow \\
\text { Insulin secretion } \downarrow\end{array}$ & $\begin{array}{l}\text { Obesity } \\
\text { Insulin resistance } \\
\text { Hyperinsulinemia }\end{array}$ \\
\hline \multirow[t]{3}{*}{ Now } & & \\
\hline & Type 1 diabetes & Type 2 diabetes \\
\hline & $\begin{array}{c}\text { Beta cell destruction } \\
\text { Beta cell mass } \downarrow \\
\text { Insulin secretion } \downarrow\end{array}$ & $\begin{array}{c}\text { Beta cell loss } \\
\text { Beta cell mass } \downarrow \\
\text { Insulin secretion } \downarrow\end{array}$ \\
\hline Causes & Autoimmune & $\begin{array}{l}\text { Insulin resistance } \\
\text { Beta cell overwork }\end{array}$ \\
\hline
\end{tabular}

Figure 1: Concepts of pathogenesis of type 1 and type 2 diabetes.

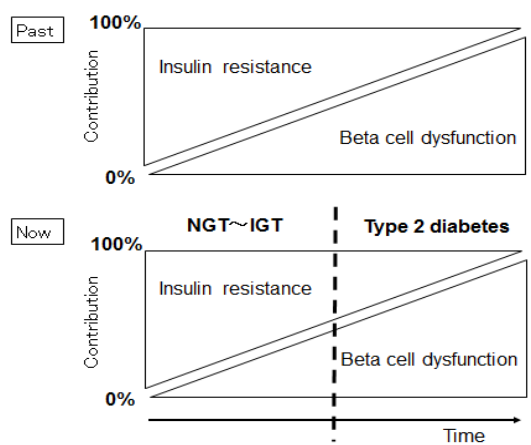

Figure 2: Relative contribution of insulin resistance and beta cell dysfunction in type 2 diabetes. NGT: Normal Glucose Tolerance; IGT: Impaired Glucose Tolerance. be increased. Increased workload of beta cells may result in beta cell death through various mechanisms such as Endoplasmic Reticulum (ER) stress, oxidative stress and amyloid deposits. Reduced function and/or mass of beta cells will result in a further increase in workload of residual beta cells. After the development of T2DM, glucolipotoxicity also worsens beta cell functional mass. This vicious cycle may underlie the progressive nature of T2DM.

Taking these findings into account, one can consider that reduced functional beta cell mass is essential for the development of T2DM, and insulin resistance is a causal factor triggering reduced functional beta cell mass. Therefore, T2DM cannot develop without beta cell dysfunction, but it can develop without insulin resistance (Figure 2).

Better understanding of the pathophysiology of T2DM by healthcare professionals and patients as well as the general population is important for improving self-management ability to adhere to a healthy lifestyle. This may be a subtle change, but such subtle changes in thinking are important in changing our lifestyle and preventing the development of T2DM. We should not be lazy about changing our mind.

\section{References}

1. Nam Han C, David W, Leonor G, Pablo AM, Nita F, et al. (2013) Internationa Diabetes Federation: IDF Diabetes Atlas (6thedn), Belgium.

2. Saisho $Y$ (2015) Beta cell dysfunction: Its critical role in prevention and management of type 2 diabetes. World J Diabetes 6: 109-124.

3. Butler AE, Janson J, Bonner-Weir S, Ritzel R, Rizza RA, et al. (2003) Betacell deficit and increased beta-cell apoptosis in humans with type 2 diabetes. Diabetes 52: 102-110.

4. DeFronzo RA, Abdul-Ghani MA (2011) Preservation of beta-cell function: the key to diabetes prevention. J Clin Endocrinol Metab 96: 2354-2366.

5. Saisho Y, Butler AE, Manesso E, Elashoff D, Rizza RA, et al. (2013) b-cel mass and turnover in humans: Effects of obesity and aging. Diabetes Care 36: 111-117.

6. Rahier J, Guiot Y, Goebbels RM, Sempoux C, Henquin JC (2008) Pancreatic beta-cell mass in European subjects with type 2 diabetes. Diabetes Obes Metab 4: 32-42.

7. Kou K, Saisho Y, Satoh S, Yamada T, Itoh H (2013) Change in beta-cell mass in Japanese nondiabetic obese individuals. J Clin Endocrinol Metab 98: 3724 3730.

8. Polonsky KS, Given BD, Van Cauter E (1988) Twenty-four-hour profiles and pulsatile patterns of insulin secretion in normal and obese subjects. J Clin Invest 81: 442-448.

*Corresponding author: Yoshifumi Saisho, Department of Internal Medicine Keio University School of Medicine, 35 Shinanomachi, Shinjuku-ku, Tokyo, Japan, Tel:+81-3-3353-1211; Fax: +81-3-3359-2745; E-mail: ysaisho@keio.jp

Received: October 29, 2015; Accepted: November 02, 2015; Published: November 04, 2015

Citation: Saisho Y (2015) Changing Our Mind: Beta Cell Workload Hypothesis. Diabetes Case Rep 1:e101. doi: 10.4172/2572-5629.1000e101

Copyright: (c) 2015 Saisho Y. This is an open-access article distributed under the terms of the Creative Commons Attribution License, which permits unrestricted use, distribution, and reproduction in any medium, provided the original author and source are credited. 